\title{
Soil Health and Related Ecosystem Services in Organic Agriculture
}

\author{
Lynette K. Abbott ${ }^{1} \&$ David A. C. Manning ${ }^{2}$ \\ ${ }^{1}$ School of Earth and Environment and UWA Institute of Agriculture, The University of Western Australia, \\ 6009 WA, Australia \\ ${ }^{2}$ School of Civil Engineering and Geosciences, Newcastle University, Newcastle upon Tyne, NE1 7RU, UK \\ Correspondence: Lynette K. Abbott, School of Earth and Envionment and UWA Institute of Agriculture, The \\ University of Western Australia, 6009, Australia. Tel: 61-8-6488-5551. E-mail: Lynette.Abbott@uwa.edu.au
}

Received: February 15, 2015 Accepted: May 10, 2015 Online Published: June 20, 2015

doi:10.5539/sar.v4n3p116 URL: http://dx.doi.org/10.5539/sar.v4n3p116

\begin{abstract}
Soil health is dependent upon complex bio-physical and bio-chemical processes which interact in space and time. Microrganisms and fauna in soil comprise highly diverse and dynamic communities that contribute, over either short or long time frames, to the transformation of geological minerals and release of essential nutrients for plant growth. Certified organic soil management practices generally restrict the use of chemically-processed highly soluble plant nutrients, leading to dependence on nutrient sources that require microbial transformation of poorly soluble geological minerals. Consequently, slow release of nutrients controls their rate of uptake by plants and associated plant physiological processes. Microbial and faunal interactions influence soil structure at various scales, within and between crystalline mineral grains, creating complex soil pore networks that further influence soil function, including the nutrient release and uptake by roots. The incorporation of organic matter into soil, as either manure or compost in organic farming systems is controlled to avoid excessive release of soluble nutrients such as nitrogen and phosphorus, while simultaneously contributing an essential source of carbon for growth and activity of soil organisms. The interdependence of many soil physical and chemical processes contributing to soil health is strongly linked to activities of the organisms living in soil as well as to root structure and function. Capitalizing on these contributions to soil health cannot be achieved without holistic, multiscale approaches to nutrient management, an understanding of interactions between carbon pools, mineral complexes and soil mineralogy, and detailed examination of farm nutrient budgets.
\end{abstract}

Keywords: soil biological fertility, mineral nutrient sources, organic matter, soil biodiversity, local knowledge

\section{Introduction}

Organic agricultural practices are underpinned by soil biological processes that are influential in the supply of nutrients to plants as well as to the creation of beneficial soil structural conditions for plant growth (Mader et al., 2002; Bhadauria \& Sazena, 2010). Both bio-physical and bio-chemical processes are central to the effectiveness of organic productive systems (Gomiero et al., 2011). Provision of an adequate supply of nutrients in certified organic farming systems can be challenging if they depend on sources of low solubility (Quilty \& Cattle, 2011). Furthermore, the avoidance of loss of nutients into the surrounding environment, including loss to groundwater, is also a high priority for organic systems (Askegaard et al., 2011). The effectiveness of use of nutrients in organic farming systems depends on the rate of cycling of nutrients from both organic matter and allowable minerals, which differ in magnitude according to the soil's inherent fertility (Heitkamop et al., 2011) and mineralogical composition (van Straaten, 2002). Globally, soils used for organic agriculture range from deep, highly fertile soils to shallow, highly weathered and nutrient depleted soils (Chivenge et al., 2011). The nutrient amendments required in organic agriculture therefore vary considerably depending on the local soil and environmental conditions, and potential level of productivity at the location of the farm (French \& Schultz, 1984).

\subsection{Soil Biological Fertility}

A major component of soil fertility in organic farming systems depends on biological processes that sit within the framework of organic certification (Fließbach et al., 2007). Soil biological fertility has been defined as "the capacity of organisms living in soil (microorganisms, fauna and roots) to contribute to the nutritional requirements of plants and foraging animals for productivity, reproduction and quality (considered in terms of 
human and animal wellbeing) while maintaining biological processes that contribute positively to the physical and chemical state of soil." (Abbott \& Murphy, 2003). Organic certification emphasises agricultural management practices that support soil biological processes (Gomiero et al., 2011) contributing significantly to the nutritional status of soil. Supplying adequate levels of nutrients for plant growth in organic systems is complex where it depends on soil processes for nutrient release. Excessive nutrient concentrations in the soil solution can arise if high quantities of manure are added to soil (Foissy et al., 2013). Therefore, this needs to be managed carefully to avoid nutrient loss. Although soil structure is largely dependent on the parent material, enhancement of biological processes can improve soil aggregation (Pulleman et al., 2005; Six et al., 2004), access to water (Augé, 2001), and reduce hard setting when combined with an appropriate quantity of organic matter (Djajadi et al., 2012).

Agricultural practices such as tillage, crop rotation and organic amendments significantly influence soil chemical and physical fertility (Birkhofer et al., 2008). They alter the rate of release of nutrients for plant uptake and growth of roots leading to both direct and indirect effects on plant production and delivery of ecosystem services (Sandhu et al., 2010). Tillage can hasten soil structure deline (Conceicao et al., 2013) but it is difficult to avoid in organic systems although no-till organic options are being explored (Carr et al., 2011). There is evidence that negative effects of tillage on some beneficial biological processes such as the accumulation of soil microbial biomass, may be less marked in tilled organic sytems compared with conventionally tilled systems (Larsen et al., 2014).

In agricultural systems where large quantities of relatively soluble synthetic fertilisers are used, some soil biological processes (such as nitrogen fixation and colonisation of roots by arbuscular mycorrhizal fungi) can be over-ridden, and their contributions may not be fully realised for agricultural production (Richardson et al., 2011) or efficient resource use (Rice et al., 2002). On the other hand, the slow rate of release of nutrients from recalcitrant sources of minerals (Manning, 2008, 2010) or from plant residues (Damon et al., 2014) may restrict plant production in organic systems compared with conventional agricutural systems. While this is commonly viewed as a deficiency of organic systems, alignment of productivity at a particular site to that which is sustainable in the longer term, based on lower risk potential (Tiedemann \& Latacz-Lohmann, 2013) is fundamental to organic agriculture. In some environments, organic production may lead to 'mining' or reduction of existing nutrient resources (Romanya \& Rovira, 2009), some of which may have been added to soil prior to organic certification. Soil fertility in organic farming systems is complex, and needs to be considered locally according to (i) existing and previous soil conditions, (ii) environmental conditions, including environmental change, (iii) plant requirements at different stages of their growth cycles, (iv) quantify of nutrients removed in grain or consumption of forage, (v) rotational sequences, (vi) soil disturbance, and (vi) economic models employed by the farmer.

\subsection{Soil Biodiversity}

Soil biodiversity is important in effective management of organic farming systems for chemical and physical fertility. Soil organisms need to be managed to ensure they contribute at optimal levels within and between seasons. For many soil organisms, their collective contributions depend on the form and quantity of organic matter in the soil and on environmental conditions that occur at the scale of soil aggregates, roots and soil pores (Rillig \& Mummey, 2006). For other organisms, such as those that are involved in nitrification (de Gannes et al., 2014), indirect relationships with mineralisation of organic matter can influence nitrogen cycling, including nitrogen loss. They may be significantly influenced by soil chemical conditions such as $\mathrm{pH}$ (Bramley and White 1990) and soil physical conditions such as compaction and water-logging (Engelaar et al., 2000).

The diversity of soil organisms varies within and among soils managed according to the guidelines of organic certification (Hartmann et al., 2014). Furthermore, there are dynamics in activity and relative abundance of soil organisms in response to availability of substrate or following nutrient application. The extreme diversity of soil organisms builds redundancy in function (Wolters, 2001; Chaer et al., 2009). Long-term reduction in organic inputs into soil can reduce the capacity of the community to mineralise some recalcitrant organic carbon fractions in soil (Paterson et al., 2011) and harsh conditions can minimise some functions (Liebich et al., 2007). It is likely that there are threshold levels of relative abundance and/or diversity for optimal function for some communities of soil organisms (Philippot et al., 2014). Soil biodiversity varies according to soil type, location and management practices (Paterson et al., 2011). However, the potential impact of changes in diversity, dominance and abundance of communities of soil organisms may or may not affect soil conditions for plant growth.

In addition to differences in the diversity, relative abundance and biomass of organisms in soil, there are 
considerable differences in their function (McGuire \& Treseder, 2010). It is not easy to equate diversity patterns of soil microbial communities, levels of microbial biomass, or levels of soil microbial respiration to 'ideal' soil conditions for their growth because temporal dynamics in suitable carbon substrate (Hoyle \& Murphy, 2011) or water deficit (Kakumanu \& Williams, 2014) can influence their abundance and activity. Most organisms go through periods of inactivity because local conditions are temporarily unsuitable (Bardgett, 2002). There is evidence of increased diversity of some groups of soil organisms with conversion to organic farming practices. For example, the diversity of arbuscular mycorrhizal fungi was higher in organic fields, and similar to that of natural grassland, compared with conventional agricultural mangement (Verbruggen et al., 2010). In a comprehensive comparison of soil microbial diversity in the long term DOK Trial in Switzerland, diversity of both soil bacteria and fungi were markedly affected by organic farming practices (Hartmann et al., 2014). Five farming systems were examined, three of which had organic management. Application of nutrients had a larger impact on soil microbial communities compared with plant protection practices used. There were distinct microbial communities in the different farming systems and these differences were less affected by spatial heterogeneity or temporal change. The higher resolution of microbial communities identified in this study compared with previous studies at the same site showed that, most likely the application of farm yard manure had a significant influence on microbial community structure (Hartmann et al., 2014). The differences between microbial communities in the organic and conventionally managed land in this study were largely attributed to the form and amount of organic fertiliser. Hartmann et al. (2014) noted that despite the higher diversity of bacteria and fungi in organically managed soil, the functional significance of this finding is not well understood. In this case, the higher diversity was closely associated with application of organic fertiliser, rather than other organic practices such as integrated pest management. Differences in tillage practice were not specifically investigated here, but they could also be expected to have significant effects on microbial community structure in organic farming systems (Yang et al., 2013).

Levels of soil microbial biomass and gas fluxes in organic farming systems can be higher than in conventional systems and are commonly linked to levels of organic matter (Chirinda et al., 2010). However, soils differ widely in their potential to protect organic matter from mineralisation (Zimmermann et al., 2012). This in turn relects on differences in microbial activity associated with mineralisation. Therefore, although the level of microbial activity in soil may be higher in organic than in conventionally managed farming systems (Gunapala \& Scow, 1998), it may not be indicative of plant productivity because many factors combine to define achievable levels of plant yield. On the other hand, higher microbial activity may contribute to greater loss of nutrients from soil for some combinations of organic management practices, including use of cover crops and tillage.

Differences in clay, loam or sand content of soil influence thresholds for 'ideal' levels of microbial biomass but benchmarks also depend on local conditions. A sandy soil may temporarily be highly biologically active leading to rapid depletion of organic matter because the organic resources are not well protected in soils with low structural stability. In constrast, a more clayey soil may display less marked peaks and troughs in microbial respiration than a sandy soil in response to mineralisation of organic matter because of its higher structural stability and greater capacity to protect organic matter (Djajadi et al., 2012). Overall, 'effective biological functioning' of soils under organic management differs widely according to soil type and location in the landscape, plant production practices, irrigation practices and nutrient inputs (Chirinda et al., 2010). Local benchmarking according to soil type, management practice and environmental condition is necessary because of the complexity of relationships between microbial activity, microbial diversity and plant response.

\subsection{Bio-Physical and Bio-Chemical Processes}

Bio-physical processes underlie structural configurations in soil and influence soil aggregation (Rillig \& Mummey, 2006), mineral dissolution (DeJong et al., 2013), water and nutrient access by roots (Dunbabin et al. 2002), and resilience to intermittent drought stress (Thierfelder \& Wall, 2010). Furthermore, these processes occur in the same or overlapping timeframes and some organisms may simulteously be involved in more than one process (Moore, 1994). Soil organisms involved in biological perturbation contribute to mineralisation of organic matter, while soil enzymes may be involved in mineralisation of organic matter or dissolution of geological minerals (Burns et al., 2013). Soil amendment with manure, commonly used in some but not all organic agricultural systems, alters both the soil physical and chemical environment. This has flow-on effects to biological processes in soil, and complex bio-physical and bio-chemical processes are also involved (Rillig \& Mummey, 2006; Six et al., 2004). Arbuscular mycorrhizal fungi (Cavagnaro et al., 2012) are examples of a community of soil organisms that cross boundaries of chemical and physical fertility by contributing to nutrient use efficiency, soil structural development, access to water, and resistance to plant disease. Some of the bacteria and fungi involved in nutrient cycling also contribute to stabilising soil aggregates (Six et al., 2004). It is difficult 
to quanitify biological contributions to each of these process separately, and to identify their specific economic value (Abbott \& Lumley, 2014).

Organic management practices seek to maximise contributions from specific groups of soil organisms such as those involved in symbiotic nitrogen fixation, microbial facilitation of nutrient uptake at root surfaces (Verbruggen et al., 2010), and disease suppression (Benitez et al., 2007). These functions are all influenced by the physical and chemical characteristics of soil to some extent. Earthworms have particularly important roles in altering soil structure (Versteegh et al., 2014) as well as in nutrient cycling, and while their contributions may be enhanced in organically managed systems, other considerations such as the length of time in pasture or cropping can override effects of organic compared with conventional management practices on their abundance (Pulleman et al., 2005). Selectivity in incorporation of organic matter into soil by earthworms further highlights the complexity of interactions between mineralisation and soil structural contributions of earthworms in organic farming systems (Pulleman et al., 2005). Organic practices can foster contributions of both mesofauna and macrofauna to soil ecosystem functioning (Dominguez et al., 2014). Furthermore, the abundance and diversity of larger soil fauna may be less influenced by organic farming practices than by conventional management practices based on observations of species richness (Postma-Blaaaw et al., 2010). In organic systems, effective functioning of soil communities may reduce disease risk associated with increased suppressiveness of soils (Yogef et al., 2011). Plant health is a complex issue (Doring et al., 2011), especially in the context of organic farming because the emphasis is not on completely eradicating pathogens or pests; maintaining soil ecosystem function is of high priority for building resilience against the development of disease or damage caused by pests.

\section{Certification Requirements Define Nutrient Inputs}

\subsection{Examples of Allowable Mineral Sources of Nutrients}

Certification requirements define allowable nutrient sources for use in organic farming systems, and include poorly soluble forms of minerals, including rock phosphate, dolomite, lime and milled silicate rocks ('rock dust') as well as a range of sources of organic matter including compost. Certification requirements restrict use of the most soluble forms of both phosphorus and potassium (permitting mined potash salts according to circumstances), so alternative sources need to be used. Allowable sources of phosphorus differ in solubility over time and in relation to soil $\mathrm{pH}$ (Manning, 2008). Other allowable rock-based nutrient sources, including feldspars, feldspathoids and micas, can provide a range of elements such as potassium, calcium, sodium and silica, with traces of other elements, but all are low in solubility (Harley \& Gilkes, 2000). Potassium can be supplied from potassium silicate minerals containing feldspar, nepheline and mica (Manning, 2012). It is released during weathering of the rock-forming minerals, especially micas (Mohammed et al., 2014). Weathering processes are slow but depending on climate and soil properties, the quantities required for plant growth may be delivered during the season. Additionally, micas and clay minerals influence cation exchange reactions (Manning, 2012).

The rate of release of nutrients from mineral resources depends on the mineral crystal structure as well as the concentration of nutrient, and the rate of release may be increased through involvement of microorganisms by addition of composted organic matter (Manning et al., 2013). Clay minerals can form complex associations with organic matter that can influence its stability (Jundaluang et al., 2013). Humus adsorbed on clay minerals can affect the rate of release of potassium and silica when exposed to organic acids (Datta et al., 2009). For humus-depleted clay, an initial release of potassium triggered further release of potassium (Datta et al., 2009). This study showed that clay-humus complexes can restrict the release of potassium. However, there is also potential for microbial processes to increase mineral dissolution (DeJong et al., 2013).

It has been shown that individual minerals in close proximity on rock surfaces exposed to the environment can have distinctive bacterial communities (Hutchens et al., 2010). Specific bacterial isolates were found on feldspar, quartz and muscovite in the rocks studied. Fungal communities tended not to display the same level of specificity as bacterial communities (Gleeson et al., 2010). While these studies have been conducted on exposed rock surfaces, different forms of minerals were shown to influence microbial community structure when they are introduced into soil (Carson et al., 2009). In this study, mica, basalt and rock phosphate were incubated separately in soil with or without a legume. Bacterial communities on individual mineral fragments differed from those in the surrounding soil. Thus, addition of poorly soluble minerals to soil could create microhabitats and contribute to spatial variation in bacterial communities (Carson et al., 2009); this in turn may support highly diverse microbial communities in organic farming systems with specific rock-mineralising capabilities.

\subsection{Examples of Sources of Nutrients From Organic Matter}

Organic matter is the primary source of many nutrients in organic farming systems (Heitkamop et al., 2011). Retention of organic matter is essential for good management and provides other benefits to soil conditions for 
plant growth. Microbial processes are involved in effective recovery of nutrients from manure and composted organic matter resulting in the release of essential plant nutrients during interactions with soil fauna, including earthworms (Bhadauria \& Sazena, 2010). Higher levels of microbial activity in soil under organic managment may not necessarily lead to increased access to stable forms of phosphorus in organic matter (Keller et al., 2012). Re-use of organic 'wastes' (e.g. manure), when permitted by organic cerification, can contribute valuable sources of nutrients in organic farming systems (Heitkamop et al., 2011; Fließbach et al., 2007). Combinations of composted organic matter and clay-based minerals can increase the rate of release of nutrients from rock minerals (Manning et al., 2013).

Stable isotope tracing is used to identify relationships between the nitrogen, phosphorus and carbon cycles in soil by tracking nutrients through the complex pathways (Dungait et al., 2012a). Near edge X-ray fine structure spectroscopy and scanning transmission X-ray microscopy have potential to provide new opportunities for three-dimensional investigation of molecules in soil (Schmidt et al., 2011). There are also opportunities for clarification of "recalcitrant" vs "protected" organic matter (Dungait et al., 2012b), and for identifying the roles of different microbial communities in connected and disconnected soil pores (Carson et al., 2010).

\section{Delivery of Ecosystem Services in Organic Farming Systems}

Organic farming systems have potential to deliver a wide range of ecosystem services associated with soil health if they (i) increase efficiency in use of nutrients from less soluble sources (Manning, 2012), (ii) minimise loss of nutrients to ground and surface water bodies (Ekholm et al., 2005), (iii) release nutrients according to plant requirement (Damon et al., 2014), (iv) budget for replacement of nutrients according to their removal (Dalgaard et al., 2002), (v) reduce the susceptibility of plants to disease (Postma et al., 2008), (vi) reduce erosion by minimising tillage (Peigné et al., 2014), and (vii) increase access to water during periods of low-rainfall (Thierfelder \& Wall, 2010). Use of comprehensive whole-farm nutrient budgets (Dalgaard et al., 2002) increases the likelihood of maximising nutrient use efficiency. Successful delivery of ecosystem services attributed to organic management may be constrained by environmental conditions and soil type (including inherent levels of soil fertility based on the source of parent rock).

Interestingly, Adl et al. (2011) concluded that the conventional agricultural practice of using pesticides can provide benefits to organic systems if they lower the threshold of disease locally. For example, if the ratio of the area of organic to adjacent conventional farmland is kept below a threshold level, the pest population can remain low. If the area ratio exceeds the threshold, the pest population can increase in the organically managed area, increasing risk to the conventionally managed area. In this case, the area under organic agriculture could be a pest reservoir.

Organic agricultural practices related to soil health provide a model for addressing the challenging issue of maximizing beneficial soil biological processes in agriculture generally, not just in organic systems. Local conditions will constrain the extent to which biological processes can proceed effectively. Furthermore, the biological status of soil is dynamic, and differs in magnitude according to season, soil type and management history (Zelenev et al., 2006; Hoyle \& Murphy, 2011; Le Guillou et al., 2012). Benchmarks are not easily attained for any of the soil parameters that could be measured because of this variability. An important aspect of organic systems is the simultaneous focus on phosphorus as well as nitrogen cycles, in contrast to many current conventional practices, but attention also needs to focus on potassium. Finally, organic systems are practiced on soils that vary widely in structure and inherent fertility, and they differ in their exposure to climatic and environmental conditions. Therefore, caution is required in generalising about issues related to soil health in organic farming systems because on-farm management efficiency differs. Nevertheless, there is a continual requirement to minimise detrimental environmental impacts, maximize nutrient use efficency, re-use waste, and manage the soil for sustainable agricultural production.

\section{Conclusion}

Organic farming practices have the potential to contribute significantly to ecosystem services in a number of ways. The health of soil is dependent upon complex bio-physical and bio-chemical processes which interact in space and time, and if they are managed effectively, they can make efficient use of nutrient resources and water for agricultural production. In doing so, loss of nutrients to surrounding land or water bodies or in wind erosion can be minimised. The availability of sources of phosphorus and potassium remain a significant issue for organic farms because of the requirement to use poorly soluble sources of these essential nutrients. Recent advances in microbial metagenomics and 3-D visualisation of the finest components of organic matter should lead to advances in understanding of processes that underpin transformations that support organic management. The interdependence of many soil physical and chemical processes that contribute to soil health is strongly linked to 
activities of organisms that live in soil as well as to root structure and function. An integrated approach is required to capitalize on these contributions to soil health and associated ecosystem services.

\section{Acknowledgements}

We are most grateful to OECD, USDA-NIFA and ICROFTS for the invitation and support to participate in the conference "Innovations in Organic Food Systems for Sustainable Production and Enhanced Ecosystem Services" held in Long Beach, California, in November 2014. Anjani Weerasekara, Bede Mickan and Sasha Jenkins provided valuable discussion.

\section{References}

Abbott, L. K., \& Lumley, S. (2014). Assessing economic benefits of arbuscular mycorrhizal fungi as a potential indicator of soil health. In Z. M. Solaiman, L. K. Abbott, \& A. Varma (Eds.), Mycorrhizal Fungi: Use in Sustainable Agriculture and Land Restoration (pp. 17-31) Soil Biology 41.

Abbott, L. K., \& Murphy, D. V. (2003). What is soil biological fertility? In L. K. Abbott \& D. V. Murphy (Eds.), Soil Biological Fertility - A key to sustainable land use in agriculture (pp. 1-15). The Netherlands: Kluwer Academic Publishers.

Adl, S., Iron, D., \& Kolokolnikov, T. (2011). A threshold area ratio of organic to conventional agriculture causes recurrent pathogen outbreaks in organic agriculture. Science of the Total Environment, 409, 2192-2197. http://dx.doi.org/10.1016/j.scitotenv.2011.02.026

Augé, R. M. (2001). Water relations, drought and vesicular-arbuscular mycorrhizal symbiosis. Mycorrhiza, 11, 3-42. http://dx.doi.org/10.1007/s005720100097

Askegaard, M., Olesen, J. E., Rasmussen, I. A., \& Kristensen, K. (2011). Nitrate leaching from organic arable crop rotations is mostly determined by autumn field management. Agriculture, Ecosystems and Environment, 142, 149-160. http://dx.doi.org/10.1016/j.agee.2011.04.014

Bardgett, R. D. (2002). Causes and consequences of biological diversity in soil. Zoology, 105, 367-374. http://dx.doi.org/10.1078/0944-2006-00072

Benitez, M.-S., Tustasa, F. B., Rotenberga, D., Kleinhenzb, M. D., Cardinab, J., Stinnerc, D., ... McSpadden Gardenera, B. B. (2007). Multiple statistical approaches of community fingerprint data reveal bacterial populations associated with general disease suppression arising from the application of different organic field management strategies. Soil Biology and Biochemistry, 39, 2289-2301. http://dx.doi.org/10.1016/j.soilbio.2007.03.028

Bhadauria, T., \& Sazena, K. G. (2010). Role of earthworms in soil fertility maintenance and the production o9f biogenic structures. Applied and Environmental Soil Science. http://dx.doi.org/10.1155/2010/816073

Birkhofer, K., Bezemer, T. M., Bloem, J., Bonkowski, B., Christensen, S., Dubois, D., ... Scheu, S. (2008). Long-term organic farming fosters below and aboveground biota: Implications for soil quality, biological

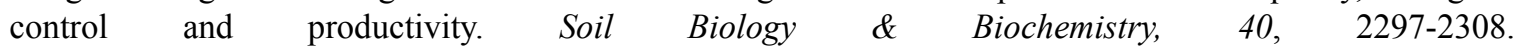
http://dx.doi.org/10.1016/j.soilbio.2008.05.007

Bramley, R. G. V., \& White, R. E. (1990). The variability of nitrifying activity in field soils. Plant and Soil, 126, 203-208. http://dx.doi.org/10.1007/BF00012823

Burns, R. G., DeForest, J. L., Marxsen, J., Sinsabaugh, R. L., Stromberger, M. E., Wallenstein, M. D., ... Zoppini, A. (2013). Soil enzymes in a changing environment: Current knowledge and future directions. Soil Biology \& Biochemistry, 58, 216-234. http://dx.doi.org/10.1016/j.soilbio.2012.11.009

Carr, P. M., Anderson, R. L., Lawley, Y. E., Miller, P. R., \& Zwinger, S. F. (2011). Organic zero-till in the northern US Great Plains Region: Opportunities and obstacles. Renewable Agriculture and Food Systems, 27, 12-20. http://dx.doi.org/10.1017/S174217051100041X

Carson, J. K., Campbell, L., Rooney, D., Clipson, N., \& Gleeson, D. B. (2009). Minerals in soil select distinct bacterial communities in their microhabitats. FEMS Microbiology Ecology, 67, 381-388. http://dx.doi.org/10.1111/j.1574-6941.2008.00645.x

Carson, J. K., Gonzalez-Quinones, V., Murphy, D. V., Hinz, C., Shaw, J. A., \& Gleeson. D. B. (2010). Low pore connectivity increases bacterial diversity in soil. Applied and Environmental Microbiology, 76, 3936-3942. http://dx.doi.org/10.1128/AEM.03085-09

Cavagnaro, T. R., Barriois-Masias, F. H., \& Jackson, L. E. (2012). Arbuscular mycorrhizas and their role in plant 
growth, nitrogen interception and soil gas efflux in an organic production system. Plant and Soil, 353, 181-194. http://dx.doi.org/10.1007/s11104-011-1021-6

Chirinda, N., Olesen, J. E., Porter, J. R., \& Schjønning, P. (2010). Soil properties, crop production and greenhouse gas emissions from organic and inorganic fertilizer-based arable cropping systems, Agriculture, Ecosystems and Environment, 139, 584-594. http://dx.doi.org/10.1016/j.agee.2010.10.001

Chivenge, P., Vanlauwe, B., Gentile, I., \& Six, J. (2011). Comparison of organic versus mineral resource effects on short-term aggregate carbon and nitrogen dynamics in a sandy soil versus a fine textured soil. Agriculture, Ecosystems and Environment, 140, 361-371. http://dx.doi.org/10.1016/j.agee.2010.12.004

Conceicao, P. C., Dieckow, J., \& Bayer, C. (2013). Combined role of no-tillage and cropping systems in soil carbon stocks and stabilization. Soil and Tillage Research, 129, 40-47. http://dx.doi.org/10.1016/j.still.2013.01.006

Dalgaard, T., Heidmann, T., \& Mogensen, L. (2002). Potential N-losses in three scenarios for conversion to organic farming in a local area of Denmark. European Journal of Agronomy, 16, $207-217$. http://dx.doi.org/10.1016/S1161-0301(01)00129-0

Damon, P. M., Bowden, B., Rose, T., \& Rengel, Z. (2014). Crop residue contributions to phosphorus pools in agricultural soils: A review. Soil Biology and Biochemistry, 74, 127-137. http://dx.doi.org/10.1016/j.soilbio.2014.03.003

Datta, C., Takkar, P. N., \& Verma, U. K. (2009). Effect of partial removal of adsorbed humus on kinetics of potassium and silica release by tartaric acid from clay-humus complex from two dissimilar soil profiles. Australian Journal of Soil Research, 47, 715-724. http://dx.doi.org/10.1071/SR09002

de Gannes, V., Eudoxie, G., \& Hickey, W. J. (2014). Impacts of edaphic factors on communities of ammonia-oxidizing archaea, ammonia-oxidizing bacteria and nitrification in tropical soils. PLoS ONE, 9(2), e89568. http://dx.doi.org/10.1371/journal.pone.0089568

DeJong, D. T., Soga, K., Kavazanjian, S., Burns, S., van Paassen, L. A., Al Qabany, A., ... Weaver, T. (2013). Biogeochemical processes and geotechnical applications: progress, opportunities and challenges. Geotechnique, 63(4), 287-301. http://dx.doi.org/10.1680/geot.SIP13.P.017

Djajadi, Abbott, L. K., \& Hinz, C. (2012). Synergistic impaces of clay and organic matter on structural and biological properties of a sandy soil. Geoderma, 183, 19-24. http://dx.doi.org/10.1016/j.geoderma.2012.03.012

Dominguez, A., Bedano, J. C., Becker, A. R., \& Arolfo, R. V. (2014). Organic farming fosters agroecosystem functioning in Argentinian temperate soils: Evidence from litter decomposition and soil fauna. Applied Soil Ecology, 83, 170-176. http://dx.doi.org/10.1016/j.apsoil.2013.11.008

Doring, T. F., Pautasso, M., Finckh, M. R., \& Wolfe, M. S. (2012). Concepts of plant health - reviewing and challenging the foundations of plant protection. Plant Pathology, 61, 1-15. http://dx.doi.org/10.1111/j.1365-3059.2011.02501.x

Dunbabin, V. M., Diggle, A. J., Rengel, Z., \& van Hugten, R. (2002). Modelling the interactions between water and nutrient uptake and root growth. Plant and Soil, 239, 19-38. http://dx.doi.org/10.1023/A:1014939512104

Dungait, J. A. J., Cardenas, L. M., Blackwell, M. S. A., Wu, L., Withers, P. J. A., Chadwick, D. R., ... Goulding, K. W. T. (2012a). Advances in the understanding of nutrient dynamics and management in UK agriculture. Science of the Total Environment, 434, 39-50. http://dx.doi.org/10.1016/j.scitotenv.2012.04.029

Dungait, J. A. J., Hopkins, D. W., Gregory, A. S., \& Whitmor, A. P. (2012b). Soil organic matter turnover is governed by accessibility not recalcitrance. Global Change Biology, 18, 1781-1796. http://dx.doi.org/10.1111/j.1365-2486.2012.02665.x

Ekholm, P., Turtola, E., Gronroos J., Seuri, P., \& Ylivainio, K. (2005). Phosphorus loss from different farming systems estimated from soil surface phosphorus balance. Agriculture, Ecosystems and Environment, 110, 266-278. http://dx.doi.org/10.1016/j.agee.2005.04.014

Engelaar, W. M. H. G., Matsumaru, T., \& Yoneyama, T. (2000). Combined effects of soil waterlogging and compaction on rice (Oryza sativa L.) growth, soil aeration, soil $\mathrm{N}$ transformations and $15 \mathrm{~N}$ discrimination. Biology and Fertility of Soils, 32, 484-493. http://dx.doi.org/10.1007/s003740000282

Fließbach, A., Oberholzer, H.-R., Gunst, L., \& Mader, P. (2007). Soil organic matter and biological soil quality 
indicators after 21 years of organic and conventional farming. Agriculture, Ecosystems and Environment, 118, 273-284. http://dx.doi.org/10.1016/j.agee.2006.05.022

Foissy, D., Vian, J.-F., \& David, C. (2013). Managing nutrient in organic farming system: reliance on lifestock production for nutrient management of arable farmland. Organic Agriculture, 3, 183-199. http://dx.doi.org/10.1007/s13165-014-0060-8

French, R. J., \& Schultz, J. E. (1984). water use efficiency of wheat in a Mediterranean-type environment. I. The relation between yield, water use and climate. Australian Journal of Agricultural Research, 35, 743-764. http://dx.doi.org/10.1071/AR9840743

Gleeson, D. B., Melville, K., McDermott, F., \& Clipson, N. (2010). Molecular Characterization of Fungal Communities in Sandstone. Geomicrobiology Journal, $27, \quad 559-571$. http://dx.doi.org/10.1080/01490451003702982

Gomiero, T., Pimentel, D., \& Paoletti, M. G. (2011). Environmental impact of different agricultural management practices: conventional vs. organic agriculture. Critical Reviews in Plant Sciences, 30, 95-124. http://dx.doi.org/10.1080/07352689.2011.554355

Gunapala, N., \& Scow, K. M. (1998). Dynamics of soil microbial biomass and activity in conventional and organic farming sytems. Soil Biology and Biochemistry, 30, 815-816. http://dx.doi.org/10.1016/S0038-0717(97)00162-4

Harley, A. D., \& Gilkes, R. J. (2000). Factors influencing the release of plant nutrient elements from silicate rock powders: a geochemical overview. Nutrient Cycling in Agroecosystems, 56, 11-36. http://dx.doi.org/10.1023/A:1009859309453

Hartmann M., Frey, B., Mayer, J., Mader, P., \& Widmer, F. (2014). Distinct soil microbial diversity under long-term organic and conventional farming. The ISME Journal, 2014, 1-18

Heitkamop, F., Raupp, J., \& Ludwig, B. (2011). Soil organic matter pools and crop yields as affected by the rate of farmyard manure and use of biodynamic preparations in a sandy soil. Organic Agriculture, 1, 111-124. http://dx.doi.org/10.1007/s13165-011-0010-7

Hoyle, R. C., \& Murphy, D. V. (2011). Influence of organic residues and soil incorporation on temporal measures of microbial biomass and plant available nitrogen. Plant and Soil, 347, 53-64. http://dx.doi.org/10.1007/s11104-011-0922-8

Hutchens, E., Gleeson, D., Dermott, F., Miranda-CasoLuengo, R., \& Clipson, N. (2010). Meter-scale diversity of microbial communities on a weathered pegmatite granite outcrop in the Wicklow Mountains, Ireland; Evidence for mineral induced selection? Geomicrobiology Journal, 27, 1-14. http://dx.doi.org/10.1080/01490450903232157

Keller, M., Oberson, A., Annaheim, K. E., Tamburini, F., Mäder, P., Mayer, J., .. Bünemann, E. K. (2012). Phosphorus forms and enzymatic hydrolyzability of organic phosphorus in oils after 30 years of organic and conventional farming. Journal of Plant Nutrition and Soil Science, 175, 385-393. http://dx.doi.org/10.1002/jpln.201100177

Kakumanu, M. L., \& Williams, M. A. (2014). Osmolyte dymanics and microbial communities vary in response to osmotic more than matric water deficit gradients in two soils. Soil Biology and Biochemistry, 79, $14-24$. http://dx.doi.org/10.1016/j.soilbio.2014.08.015

Jundaluang, W., Kheoruenromne, I., Suddhiprakarn, A., Singh, B. P., \& Singh, B. (2013). Influence of soil texture and mineralogy on organic matter content and composition in physically separated fractions soils of Thailand. Geoderma, 195-196, 207-219. http://dx.doi.org/10.1016/j.geoderma.2012.12.003

Larsen, E., Grossman, J., Edgell, J., Hoyt, G., Osmond, D., \& Hu, S. (2014). Soil biological properties, soil losses and corn yield in long-term organic and conventional farming systems. Soil and Tillage Research, 139, 37-45. http://dx.doi.org/10.1016/j.still.2014.02.002

Le Guillou, C., Angers, D. A., Maron, P. A., Leterme, P., \& Menasseri-Aubry, S. (2012). Soil Biology and Biochemistry, 50, 126-133. http://dx.doi.org/10.1016/j.soilbio.2012.03.009

Liebich J., Schloter, M., Schaffer, A., Vereecken, H., \& Purauel, P. (2007). Degradation and humification of maize straw in soil microcosms inoculated with simple and complex microbial communities. European Journal of Soil Science, 58, 141-151. http://dx.doi.org/10.1111/j.1365-2389.2006.00816.x

Mader, P., Fließbach A., Dubois, D., Gunst, L., Fried, P., \& Niggli, U. (2002). Soil fertility and biodiversity in 
organic farming. Science, 296(5573), 1694-1697. http://dx.doi.org/10.1126/science.1071148

Manning, D. A. C. (2008). Phosphate minerals, environmental pollution and sustainable agriculture. Elements, 40, 105-108. http://dx.doi.org/10.2113/GSELEMENTS.4.2.105

Manning, D. A. C. (2010). Mineral sources of potassium and plant nutrition. A review. Agronomy for Sustainable Development, 30, 281-294. http://dx.doi.org/10.1051/agro/2009023

Manning, D. A. C. (2012). Plant Nutrients. In Issues in Environmental Science and Technology No. 35. Soils and Food Security. Eds Hester RE \& Harrison RM. Royal Society of Chemistry. http://dx.doi.org/10.1039/9781849735438-00183

Manning, D. A. C., Renforth, P., Lopez-Cape, E., Robertson, S., \& Ghazireh, N. (2013). Carbonate precipitation in artificial soils produced from basaltic quarry fines and composts: An opportunity for passive carbon -sequestration. International Journal of Greenhouse Gas Control, 17, 309-317. http://dx.doi.org/10.1016/j.ijggc.2013.05.012

Mohammed, S. O., Brandt, K., Gray, N. D., White, M. L. \& Manning, D. A. C. (2014). Comparison of silicate minerals as sources of K for plant nutrition in sandy soil. European Journal of Soil Science, 65, 653-662. http://dx.doi.org/10.1111/ejss.12172

Moore, J. C. (1994). Impact of agricultural practices on soil food web structure: Theory and application. Agriculture, Ecosystems and Environment, 51, 239-247. http://dx.doi.org/10.1016/0167-8809(94)90047-7

Paterson, E., Sim, A., Osborne, S. M., \& Murray, P. J. (2011). Long-term exclusion of plant-inputs to soil reduces the functional capacity of microbial communities to mineralise recalcitrant root-derived carbon sources. Soil Biology and Biochemistry, 43, 1873-1880. http://dx.doi.org/10.1016/j.soilbio.2011.05.006

Peigné, J., Messmer, M., Aveline, A., Berner, A., Mader, P., Carcea. M., ... David, C. (2014). Wheat yield and quality as influenced b7 reduced tillage in organic farming. Organic Agriculture, 4, 1-13. http://dx.doi.org/10.1007/s13165-013-0055-x

Philippot, L., Spor, A., Henault, C., Bru, D., Bizouard, F., Jones, C. M., ... Maron, P.-A. (2013). Loss in microbial diversity affects nitrogen cycling in soil. The ISME Journal, 7, 1609-1619. http://dx.doi.org/10.1038/ismej.2013.34

Postma, J., Schilder, M. T., Bloem, J., \& van Leeuwen-Haagsma, W. K. (2008). Soil suppressiveness and functional diversityof the soil microflora in organic farming systems. Soil Biology and Biochemistry, 40, 2394-2406. http://dx.doi.org/10.1016/j.soilbio.2008.05.023

Postma-Blaaaw, M. B., de Goede, R. G. M., Bloem, J., Faber, J. H., \& Brussaard, L. (2010). Soil biota community structure and abundance under agricultural intensification and extensification. Ecology, 91(2), 460-473. http://dx.doi.org/10.1890/09-0666.1

Pulleman, M. M., Six, J., Uyla, A., Marinissena, J. C. Y., \& Jongmans, A. G. (2005). Earthworms and management affect organic matter incorporation and microaggregate formation in agricultural soils. Applied Soil Ecology, 29, 1-15. http://dx.doi.org/10.1016/j.apsoil.2004.10.003

Quilty, J. R., \& Cattle, S. R. (2011). Use and understanding of organic amendments in Australian agriculture: A review. Soil Research, 49, 1-26. http://dx.doi.org/10.1071/SR10059

Richardson A. E., Lynch, J. P., Ryan, P. R., Delhaize, E., Smith, F. E., Smith, S. E., ... Simpson, R. J. (2011). Plant and microbial strategies to improve the phosphorus efficiency of agriculture. Plant and Soil, 349, 121-156. http://dx.doi.org/10.1007/s11104-011-0950-4

Rillig, M., \& Mummey, D. L. (2006). Mycorrhizas and soil structure. New Phytologist, 171, 41-53. http://dx.doi.org/10.1111/j.1469-8137.2006.01750.x

Romanya, J., \& Rovira, P. (2009). Organic and inorganic P reserves in raid-fed and irrigated calcareous soils under long term organic and conventional agriculture. Geoderma, 151, 378-386. http://dx.doi.org/10.1016/j.geoderma.2009.05.009

Sandhu, H. S., Wratten, S. D., \& Cullen, R. (2010). Organic agriculture and ecosystem services. Environmental Science and Policy, 13, 1-7. http://dx.doi.org/10.1016/j.envsci.2009.11.002

Schmidt, M. W. I., Torn, M. S., Abiven, S., Dittmar, T., Guggenberger, G., Janssens, I. A., ... Trumbore, S. E. (2011). Persistence of soil organic matter as an ecosystem property. Nature, 478, 49-56. http://dx.doi.org/10.1038/nature10386 
Six, J., Bossuyt, H., Degryze, S., \& Denef, K. (2004). A history of research on the link between (micro)aggregates, soil biota, and soil organic matter dynamics. Soil and Tillage Research, 79, 7-31. http://dx.doi.org/10.1016/j.still.2004.03.008

Van Straaten, P. (2002). Rocks for Crops: Agrominerals of sub-Saharan Africa. ICRAF, Nairobi, Kenya.

Versteegh, E., Black, S., \& Hodson, M. E. (2014). Environmental controls on the production of calcium carbonate by earthworms. Soil Biology and Biochemistry, 70, 159-161. http://dx.doi.org/10.1016/j.soilbio.2013.12.013

Verbruggen, E., Roling, W. F. M., Gamper, H. A., Kowalchuk, G. A., Verhoef, H. A., \& van der Heijden, M. G. A. (2010). Positive effects of organic farming on below-ground mutualists: large-scale comparison of mycorrhizal fungal communities in agricultural soils. New Phytologist, 186, 968-979. http://dx.doi.org/10.1111/j.1469-8137.2010.03230.x

Wolters, V. (2001). Biodiversity of soil animals and its function. European Journal of Soil Biology, 37, 221-227. http://dx.doi.org/10.1016/S1164-5563(01)01088-3

Yang, Q., Wang, X., \& Shen, Y. (2013). Comparison of soil microbial community catabolic diversity between rhizosphere and bulk soil induced by tillage or residue retention. Journal of Soil Science and Plant Nutrition, 13(1), 187-199. http://dx.doi.org/10.4067/s0718-95162013005000017

Yogev, A., Laor, Y., Katan, J., Hadar, Y., Cohen, R., Medina, S., \& Raviv, M. (2011). Does organic farming increase soil suppression against Fusarium wilt of melon? Organic Agriculture, 1, 203-216. http://dx.doi.org/10.1007/s13165-011-0016-1

Zelenev, V. V., van Bruggen, A. H. C., Laffelaar, P. A., Bloem, J., \& Semenov, A. M. (2006). Oscillating dynamics of bacterial populations and their predators in response to fresh organic matter added to soil: The simulation model 'BACWAVE-WEB'. Soil Biololgy and Biochemistry, 38, 1690-1711. http://dx.doi.org/10.1016/j.soilbio.2005.11.024

Zimmermann, M., Leifeld, J., Conen, R., Bird, M. I., \& Meir, P. (2012). Can composition and physical protection of sol organic matter explain soil respiration temperature sensitivity? Biogeochemistry, 107, 423-436. http://dx.doi.org/10.1007/s10533-010-9562-y

\section{Copyrights}

Copyright for this article is retained by the author(s), with first publication rights granted to the journal.

This is an open-access article distributed under the terms and conditions of the Creative Commons Attribution license (http://creativecommons.org/licenses/by/3.0/). 